\title{
Effects of High Temperature and Thermal Cycling on the Performance of Perovskite Solar Cells: Acceleration of Charge Recombination and Deterioration of Charge Extraction
}

\author{
Arif D. Sheikh, Rahim Munir, Md Azimul Haque, Ashok Bera, \\ Weijin Hu, Parvez Shaikh, Aram Amassian, and Tom Wu
}

ACS Appl. Mater. Interfaces, Just Accepted Manuscript • DOI: 10.1021/acsami.7b11250 • Publication Date (Web): 18 Sep 2017

Downloaded from http://pubs.acs.org on September 25, 2017

\section{Just Accepted}

"Just Accepted" manuscripts have been peer-reviewed and accepted for publication. They are posted online prior to technical editing, formatting for publication and author proofing. The American Chemical Society provides "Just Accepted" as a free service to the research community to expedite the dissemination of scientific material as soon as possible after acceptance. "Just Accepted" manuscripts appear in full in PDF format accompanied by an HTML abstract. "Just Accepted" manuscripts have been fully peer reviewed, but should not be considered the official version of record. They are accessible to all readers and citable by the Digital Object Identifier (DOI®). "Just Accepted" is an optional service offered to authors. Therefore, the "Just Accepted" Web site may not include all articles that will be published in the journal. After a manuscript is technically edited and formatted, it will be removed from the "Just Accepted" Web site and published as an ASAP article. Note that technical editing may introduce minor changes to the manuscript text and/or graphics which could affect content, and all legal disclaimers and ethical guidelines that apply to the journal pertain. ACS cannot be held responsible for errors or consequences arising from the use of information contained in these "Just Accepted" manuscripts. 


\title{
Effects of High Temperature and Thermal Cycling on the Performance of Perovskite Solar Cells: Acceleration of Charge Recombination and Deterioration of Charge Extraction
}

\author{
Arif D Sheikh ${ }^{1,2, \dagger}$, Rahim Munir ${ }^{2}$, Md Azimul Haque ${ }^{1}$, Ashok Bera ${ }^{1}$, Weijin $\mathrm{Hu}^{1}$, Parvez \\ Shaikh $^{1 \dagger \dagger}$, Aram Amassian ${ }^{1,2}$ and Tom $\mathrm{Wu}^{1 *}$ \\ ${ }^{1}$ Physical Sciences and Engineering Division (PSE), King Abdullah University of Science and \\ Technology (KAUST), Thuwal, 23955-6900, Saudi Arabia \\ ${ }^{2}$ KAUST Solar Center, King Abdullah University of Science and Technology (KAUST), \\ Thuwal, 23955-6900, Saudi Arabia \\ ${ }^{\dagger}$ Present Address: School of Nanoscience and Technology, Shivaji University, Kolhapur- \\ 411004, India. \\ ${ }^{\dagger \dagger}$ Present Address: Department of Physics, Poona College, Pune-411001, Maharashtra, \\ India. \\ *Corresponding author, email: tao.wu@kaust.edu.sa
}

Keywords: Perovskite solar cell; thermal cycle; Spiro-OMeTAD; charge transfer; charge recombination 


\begin{abstract}
In this work, we investigated the effects of high operating temperature and thermal cycling on the photovoltaic performance of perovskite solar cells (PSCs) with a typical mesostructured (m)- $\mathrm{TiO}_{2}-\mathrm{CH}_{3} \mathrm{NH}_{3} \mathrm{PbI}_{3-\mathrm{x}} \mathrm{Cl}_{\mathrm{x}}$-spiro-OMeTAD architecture. After carrying out temperature-dependent grazing incidence wide-angle X-ray scattering (GIWAXS), in-situ Xray diffraction (XRD) and optical absorption experiments, thermal durability of PSCs was tested by subjecting the devices to repetitive heating to $70{ }^{\circ} \mathrm{C}$ and cooling to room temperature $\left(20^{\circ} \mathrm{C}\right)$. An unexpected regenerative effect was observed after the first thermal cycle; the average power conversion efficiency (PCE) increased by approximately $10 \%$ in reference to the as-prepared device. This increase of PCE was attributed to the heatinginduced improvement of crystallinity and p-doping in the hole-transporter, Spiro-OMeTAD, which promotes the efficient extraction of photo-generated carriers. However, further thermal cycles produced a detrimental effect on the photovoltaic performance of PSCs with shortcircuit current and fill factor degrading faster than the open-circuit voltage. Similarly, the photovoltaic performance of PSCs degraded at high operation temperatures; both short-circuit current and open-circuit voltage decreased with increasing temperature, but the temperaturedependent trend of fill factor was opposite. Our impedance spectroscopy analysis revealed a monotonous increase of charge transfer resistance and a concurrent decrease of charge recombination resistance with increasing temperature, indicating high recombination of charge carriers. Our results revealed that both thermal cycling and high temperatures produce irreversible detrimental effects on the PSC performance due to the deteriorated interfacial photo-carrier extraction. The present findings suggest that development of robust charge transporters and proper interface engineering are critical for the deployment of perovskite photovoltaics in harsh thermal environments.
\end{abstract}




\section{INTRODUCTION}

The unprecedentedly fast rise of the efficiency of hybrid perovskite solar cells (PSCs) from $3.8 \%^{1}$ to over $20 \%,{ }^{2,3}$ with a certified current world record of $22.1 \%,{ }^{4}$ make them a promising contender in future photovoltaic technology. Halide perovskites have attracted enormous attention as light harvesting material, ${ }^{5,6}$ thanks to their extraordinary properties such as favourable electrical properties, ${ }^{7,8}$ tunable optical band gap, ${ }^{9,10}$ long carrier diffusion lengths ${ }^{11,12}$ and solution processability. ${ }^{13-15}$ Intensive efforts have been devoted to improving the morphology and properties of the perovskite layers, optimizing the processing techniques, ${ }^{16-23}$ identifying new electron and hole transport materials, ${ }^{24-31}$ aiming at enhancing the overall photovoltaic performance. Despite these exciting developments in this research field, the stability of PSCs in ambient conditions with varying conditions of temperature, illuminations and moisture remains as the main bottleneck impeding their large-scale industrial commercialization. ${ }^{32-34}$ It has been reported that decomposition of $\mathrm{CH}_{3} \mathrm{NH}_{3} \mathrm{PbI}_{3}$ $\left(\mathrm{MAPbI}_{3}\right)$ into $\mathrm{PbI}_{2}, \mathrm{I}_{2}$, and methylamine (MA) could be triggered by humid air and light. ${ }^{35-37}$ Particularly, for outdoor applications of PSCs, the geographical location and the operating environments may vary drastically. For commercial solar cells, specific endurance tests like thermal-cycling test, humidity-freeze test, light soaking test, and damp heat test are required before the devices or modules can be put into end-user applications. ${ }^{38}$ Therefore, it is important to identify and understand the impact of such environmental elements on the performance of PSCs.

This work focuses on the thermal effects on the photovoltaic performance of PSCs. It is known that temperature has significant effects on the crystal structure, phase transition and degradation of the organic-inorganic hybrid perovskites. So far there have been a few reports dedicated to understanding the temperature-dependent performance of PSCs. In one early work, Li et al. investigated the outdoor performance and stability of mesoporous PSCs. ${ }^{39}$ In 
another work on carrier transport, Milot et al. reported that charge carrier diffusion length and mobility in $\mathrm{MAPbI}_{3}$ gradually decreases with increasing temperature. ${ }^{40}$ In order to improve thermal stability, Aharon et al. fabricated $\mathrm{FAPbI}_{3}$-based hole-conductor-free PSCs which exhibited higher thermal stability than the commonly studied $\mathrm{MAPbI}_{3}$ counterpart. $^{41}$ In another important work, Ren et al. reported that post-synthesis annealing treatment in oxygen atmosphere improved the $\mathrm{PCE}$ of $\mathrm{MAPbI}_{3}$-based planar $\mathrm{PSCs},{ }^{42}$ but the underlying mechanism remains unclear. In a later work focusing on the heating-induced compositional modifications, Divitini et al. reported in-situ TEM observation of mesostructured perovskite solar cells being heated to high temperatures, ${ }^{43}$ and they observed chemical changes, such as iodine and lead migration during the thermal treatment. In another work, Domanski et al. found that when PSCs are heated to $75{ }^{\circ} \mathrm{C}$ for a very extended period of time $(16 \mathrm{~h})$, gold from the top electrode started to migrate through the spiro-OMeTAD layer into the perovskite layer, which represents another pathway of degradation at high temperatures. ${ }^{44}$ However, an in-depth analysis of the thermal stability of PSCs is still lacking, which limits the further advent of perovskite-based technologies. Furthermore, the impact of thermal environment, particularly high temperatures and thermal cycling, on the structural, morphological and electronic properties of perovskite layers and PSCs need to be identified.

In this work, repeated heating (to $70{ }^{\circ} \mathrm{C}$ ) and cooling (to $20^{\circ} \mathrm{C}$ ) processes were used to mimic the operating conditions of PSCs in a harsh environment, and our focus is to evaluate the effect of thermal cycling on the performance of PSCs. Our experiments revealed that within the temperature window $\left(20{ }^{\circ} \mathrm{C}-70{ }^{\circ} \mathrm{C}\right)$, the thermal process detrimentally affected the charge transporter, particularly spiro-OMeTAD, much more than the perovskite layer. Particularly, we found that the thermal annealing, in the beginning, improved the crystallinity and charge transport of the hole-transporting material (HTM), leading to the initial enhancement of photovoltaic performance after the first thermal cycle. However, the current 
density-voltage $(J-V)$ and incident photon to current conversion efficiency (IPCE) measurements indicated that the Photovoltaic (PV) performance of PSCs generally degraded at higher operating temperatures. Furthermore, impedance spectroscopy analysis of the PSCs revealed the monotonous increase of charge transfer resistance and the concurrent decrease of charge recombination resistance with increasing temperature. We also found that multiple thermal cycling steps on PSCs produced a similar detrimental effect, i.e., reducing the photovoltaic performance via increasing the recombination of charge carriers. These results provide valuable insights on the photo-carrier extraction and charge recombination processes in the PSCs under conditions of high operating temperatures and repetitive thermal cycles.

\section{EXPERIMENTAL SECTION}

\subsection{Materials and Device Fabrication}

Methylammonium iodide $\left(\mathrm{CH}_{3} \mathrm{NH}_{3} \mathrm{I}\right)$ was synthesized according to the procedure mentioned in our previous report. ${ }^{32}$ To prepare the $\mathrm{CH}_{3} \mathrm{NH}_{3} \mathrm{PbI}_{3-\mathrm{x}} \mathrm{Cl}_{\mathrm{x}}\left(\mathrm{MAPbI}_{3-\mathrm{x}} \mathrm{Cl}_{\mathrm{x}}\right)$ perovskite precursor solution, as-synthesized $\mathrm{CH}_{3} \mathrm{NH}_{3} \mathrm{I}$ powder and lead (II) chloride powder $\left(\mathrm{PbCl}_{2}\right.$, Alfa Aesar) were mixed in anhydrous dimethylformamide (DMF, Aldrich) with a weight ratio of $3: 1$. The suspension was stirred overnight at $70{ }^{\circ} \mathrm{C}$. All precursor materials were used directly without purification. Etched fluorine-doped tin oxide (FTO) coated glass substrates (Pilkington, TEC-8) were cleaned successively with detergent, deionised water, acetone and isopropanol for $15 \mathrm{~min}$ each in an ultrasonic bath. Subsequently, the substrates were treated with oxygen plasma for 3 min. A compact layer of $\mathrm{TiO}_{2}$ was deposited by spin coating a solution containing $350 \mu \mathrm{L}$ of titanium isopropoxide and $35 \mu \mathrm{L}$ of $\mathrm{HCl}$ in $5 \mathrm{~mL}$ ethanol at $2000 \mathrm{rpm}$ for $60 \mathrm{sec}$, followed by sintering at $490{ }^{\circ} \mathrm{C}$ for $60 \mathrm{~min}$. The $300 \mathrm{~nm}$ thick mesoporous $\mathrm{TiO}_{2}$ layer was deposited by spin coating (2000 r.p.m. for 60 s) solutions of commercial dyesol paste (18 NR-T) diluted in ethanol (1:5 weight ratio). Subsequent to the 
initial drying step at $150{ }^{\circ} \mathrm{C}$ for $20 \mathrm{~min}$, the $\mathrm{TiO}_{2}$ film was sintered at $490{ }^{\circ} \mathrm{C}$ for 60 min. After the film was cooled to $\mathrm{RT}$, the $\mathrm{MAPbI}_{3-\mathrm{x}} \mathrm{Cl}_{\mathrm{x}}$ perovskite precursor solution was spin coated at 1000 r. p. m. for $10 \mathrm{sec}$ and 2000 r. p. m. for $60 \mathrm{sec}$ onto the substrate with subsequent chlorobenzene drop after $40 \mathrm{sec}$. The substrate was transferred to a hot plate preheated to $95{ }^{\circ} \mathrm{C}$, and the thermal treatment lasted for 80 min in a $\mathrm{N}_{2}$-filled glove box. A hole-transporting layer was then deposited in air via spin-coating a $0.79 \mathrm{M}$ solution of spiroOMeTAD in $1 \mathrm{ml}$ chlorobenzene, with additives of Li-TFSI and t-BP. This coating process was carried out at $2000 \mathrm{rpm}$ for $30 \mathrm{~s}$ in dry air (with the relative humidity at $20 \pm 5 \%$ ). Afterwards, the cells were left in dry air (humidity level: $20 \pm 5 \%$ ) overnight in the dark. To complete the device fabrication, $100 \mathrm{~nm}$ thick Au back contact was deposited by thermal evaporation in a vacuum chamber with a base pressure of about $10^{-5}$ bar.

\subsection{Characterizations}

GIWAXS measurements were conducted in the Cornell High Energy Synchrotron Source (CHESS) at the D1 beam line. For annealing experiments, a small hot plate was set up as a stage, which was preheated to $100{ }^{\circ} \mathrm{C}$. For all measurements, incident angle was kept at 0.25 . The UV-Vis absorbance measurements were performed using a F20-UVX spectrometer (Filmetrics, Inc.) with a tungsten halogen light source. The in-situ absorbance measurements were conducted on a pre-heated (at $100^{\circ} \mathrm{C}$ ) hot plate in a nitrogen-purged glove box with relative humidity less than $0.1 \mathrm{ppm}$. In-situ variable temperature powder XRD spectrum measurements were performed on a PANalytical X'Pert Pro MPD X-ray diffractometer equipped with a temperature-control chamber (LT chamber, TTK450 from Anton Paar GmbH). XRD patterns were collected with a Bruker D8 Advance instrument at $45 \mathrm{kV}, 40 \mathrm{~mA}$ for $\mathrm{Cu} \mathrm{K}_{\alpha}(\lambda=1.5418 \AA)$ with a scan speed of $1.0^{\circ} / \mathrm{min}$ and a step size of $0.02^{\circ}$ in $2 \theta$. The samples were held at the designated temperatures for at least 5 minutes before each scan. 
A field emission scanning electron microscope (FESEM, FEI Nano Nova) was used to acquire the cross-sectional SEM images. Bruker atomic force microscope (model ICONPKG) with a heating stage was used to identify the surface roughness of the spiro-OMeTAD film of PSCs. UV-Visible absorption spectra of the solar cells were measured on a Varian Cary 6000i spectrophotometer.

The effect of operation temperature on photovoltaic performance was studied by conducting temperature dependent dark current density - voltage $(J-V)$ characteristics. The $J$ $V$ curves were measured using a source meter (Keithley 2420) and a solar simulator (Newport, Oriel Class A, 91195A) at $100 \mathrm{~mW} / \mathrm{cm}^{2}$ illumination (AM 1.5G). The solar simulator was calibrated using a Si-reference cell certificated by NREL. All the solar cells were masked during the $J-V$ measurements to define an active area of about $0.1 \mathrm{~cm}^{2}$.

In-situ incident photon to current conversion efficiency (IPCE) and impedance spectroscopic measurements were carried out on PSCs. IPCE was measured using a Newport Oriel QE/IPCE measurement kit with a silicon photodiode detector. The impedance measurements were performed using an Autolab PG30 potentiostat. During the measurements, $A C$ voltage signals with $10 \mathrm{mV}$ in amplitude were applied in the frequency range from $0.1 \mathrm{~Hz}$ to $1 \mathrm{MHz}$ with no external $D C$ voltage (zero bias) applied to the solar cell. During the impedance measurements, the solar cells were kept in the dark at different operating temperature. To reduce noise and increase reproducibility of the data, the solar cells were kept in a faradaic cage (an electrically shielded aluminium box). During the $J-V$ and IPCE characterizations, the relative humidity level in the laboratory was $50-55 \%$. For controlling the sample temperatures, we used a heating stage with a temperature accuracy of $0.1{ }^{\circ} \mathrm{C}$, and the sample temperature was also monitored in real time using an infrared thermometer. The setup for measuring the in-situ temperature dependent performance of perovskite solar cells is shown in Figure S1 of supporting information. Prior to each heating 
and cooling cycles, the device temperature was stabilized for $5 \mathrm{~min}$ in the dark. The $J$ - $V$ characteristic, IPCE and impedance measurements were performed in the temperature range from $20{ }^{\circ} \mathrm{C}$ to $70{ }^{\circ} \mathrm{C}$ with a step increment of $10{ }^{\circ} \mathrm{C}$. This set of measurements was repeated for each sample at different temperatures to ensure the reproducibility. It should be noted that all the devices were characterized without encapsulation.

\section{RESULTS AND DISCUSSION}

\subsection{In-situ structural and absorption measurements of the $\mathrm{MAPbI}_{3-x} \mathrm{Cl}_{x}$ layer}

We first monitored the phase formation process from as-coated precursors to final perovskite films during annealing at $100{ }^{\circ} \mathrm{C}$ using the GIWAXS technique. This in-situ experiment enabled us to find the exact time required for forming the perovskite phase and getting rid of all other undesired phases during annealing. The undesired parasitic phases are mainly solvates, and their presence hinders achieving the optimal device performance. It is crucial to remove these phases and to achieve pure perovskite thin film before the deposition of the hole-transporting layer. Because our primary focus is to examine the thermal stability of PSCs, it is important to achieve the pure perovskite phase before we move ahead investigating the thermal stability and any phase decomposition.

Figure 1 shows the GIWAXS patterns for the substrate on the hot plate $\left(100{ }^{\circ} \mathrm{C}\right)$ at a different time of 1 min (1a), 20 mins (1b) and 60 mins (1c) after spin coating. It is clear that the film after $1 \mathrm{~min}$ of annealing does not have the signature of perovskite phase (at $\mathrm{q}=10$ $\mathrm{nm}^{-1}$ ), but it does have some solvate phases at $4.5 \mathrm{~nm}^{-1}$ and $5.1 \mathrm{~nm}^{-1}$. After $20 \mathrm{mins}$ of annealing, the nucleation of perovskite phase started, but the other undesirable products are still present in the film. After 60 mins of annealing, we observed only the immaculate perovskite phase ring, indicating a complete conversion of precursors to perovskite. To examine the annealing process in detail, we plotted in Figure 1d the intensity vs the q-value 
for different durations of annealing. Annealing of 1 min already produced some observable effect on the as-cast film. There was not much change from 1 min to 10 mins of annealing, and the spectra were dominated by the solvate peaks. After 20 mins, the perovskite peak emerged, and the intensity for other phases concurrently decreased. Finally, an hour of annealing generated an immaculate perovskite peak without any other observable peak. We studied the same annealing process using the in-situ UV-Vis absorption technique and plotted the results in Figure 1e. We observed that in just 10 seconds after we placed the substrate on the hot $\left(100^{\circ} \mathrm{C}\right)$ plate, the absorption edge increased from $700 \mathrm{~nm}$ to $450 \mathrm{~nm}$. Then, after 5 min, the absorption edge moved back to a higher wavelength. Finally, after 60 minutes of annealing, we got a fully converted perovskite film, which is consistent with our GIWAXS result. To get a pure perovskite phase and to get rid of all other phases in the film, annealing at $100{ }^{\circ} \mathrm{C}$ for at least 60 minutes is required.

(a)

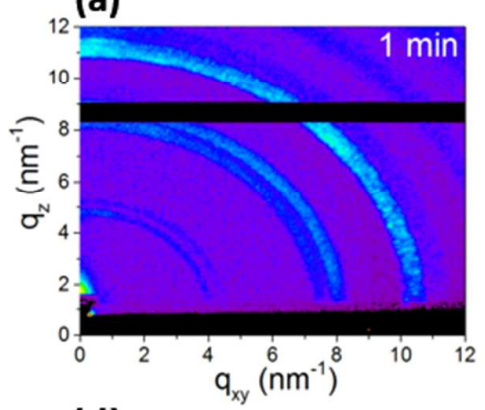

(d)

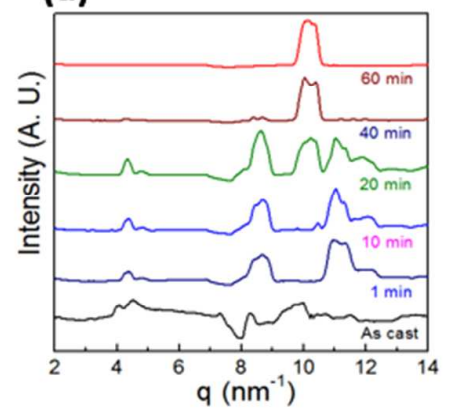

(b)

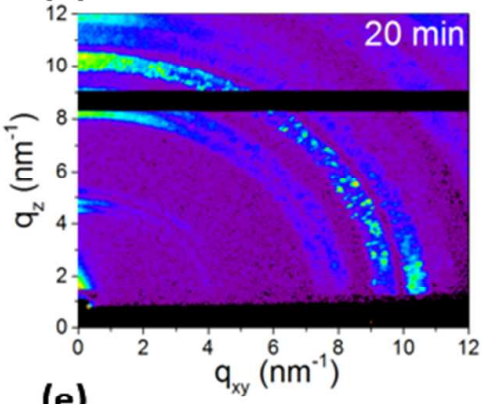

(e)

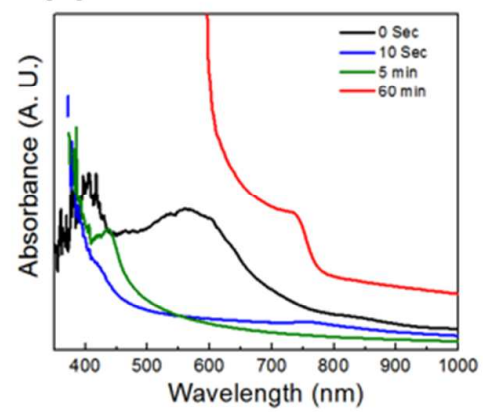

(c)

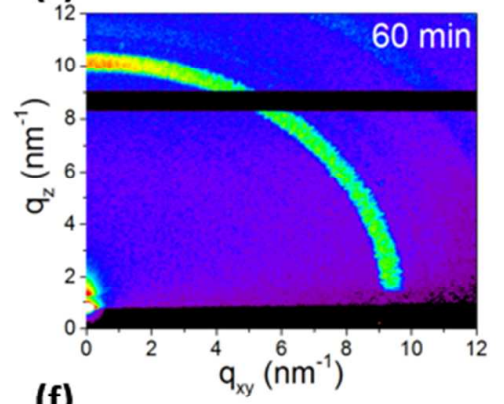

(f)

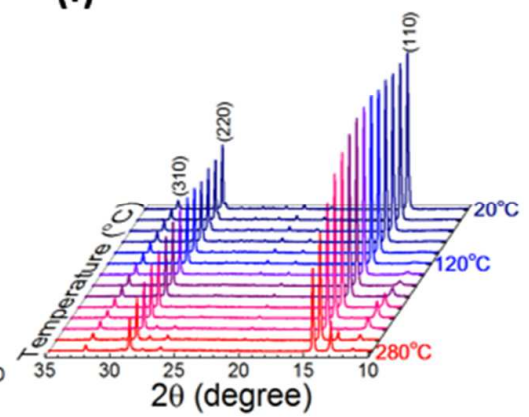

Figure 1. In-situ 2D GIWAXS patterns of the as-coated $\mathrm{MAPbI}_{3-\mathrm{x}} \mathrm{Cl}_{\mathrm{x}}$ film being annealed at $100{ }^{\circ} \mathrm{C}$ for (a) $1 \mathrm{~min}$, (b) $20 \mathrm{~min}$ and (c) $60 \mathrm{~min}$. (d) Corresponding intensity vs 'q' spectra. 
(e) In-situ annealing-dependent absorption spectra of theMAPbI${ }_{3-\mathrm{x}} \mathrm{Cl}_{\mathrm{x}}$ film taken at $0 \mathrm{~min}, 10$ sec, 5 min and 60 min after spin coating. (f) In-situ temperature-dependent X-ray diffraction patterns of the annealed $\mathrm{MAPbI}_{3-\mathrm{x}} \mathrm{Cl}_{\mathrm{x}}$ film on glass substrate.

The thermal stability of perovskite lead halides $\left(\mathrm{MAPbI}_{3} / \mathrm{MAPbI}_{3-\mathrm{x}} \mathrm{Cl}_{\mathrm{x}}\right)$ is considered as a bottleneck by the PV research community, but its exact mechanism has remained as a controversial issue. There are discrepancies regarding the decomposition temperatures of $\mathrm{MAPbI}_{3}$ reported in the literature, which could be related to the details of synthesis and characteristics of perovskite films. For example, a decomposition temperature of $280^{\circ} \mathrm{C}$ was reported using thermogravimetric measurements, ${ }^{45}$ while $140^{\circ} \mathrm{C}$ (reference 46 ) and $120^{\circ} \mathrm{C}$ (reference 47) were reported by examining ex-situ XRD patterns of annealed perovskite films. In this work, we examined the thermal stability of $\mathrm{MAPbI}_{3-\mathrm{x}} \mathrm{Cl}_{\mathrm{x}}$ films by performing insitu temperature dependent XRD measurements. The perovskite thin film was heated from 20 ${ }^{\circ} \mathrm{C}$ to $280{ }^{\circ} \mathrm{C}$ in ambient condition, and the measurements were taken with an interval step of $20{ }^{\circ} \mathrm{C}$. As shown in Figure 1f, the decomposition of $\mathrm{MAPbI}_{3-\mathrm{x}} \mathrm{Cl}_{\mathrm{x}}$ perovskite appeared to start at $120{ }^{\circ} \mathrm{C}$, indicating an unknown $\mathrm{XRD}$ peak at 11.3 degree, while the $\mathrm{PbI}_{2}$ phase characterized by the peaks at 12.6 degree was observed at higher temperatures. ${ }^{47}$ Furthermore, to verify the thermal stability of $\mathrm{MAPbI}_{3-\mathrm{x}} \mathrm{Cl}_{\mathrm{x}}$ perovskite thin films at $100{ }^{\circ} \mathrm{C}$, we performed ex-situ XRD measurements after different durations of annealing. The comparative XRD patterns of the $\mathrm{MAPbI}_{3-\mathrm{x}} \mathrm{Cl}_{\mathrm{x}}$ perovskite thin films on glass substrates, both freshly prepared and after annealing at $100{ }^{\circ} \mathrm{C}$ for $80 \mathrm{~min}, 120 \mathrm{~min}$ and $180 \mathrm{~min}$, are shown in Figure S2 of supporting information. We observed that the $\mathrm{PbI}_{2}$ peak started to appear after 80 min annealing at $100{ }^{\circ} \mathrm{C}$. The intensity of $\mathrm{PbI}_{2}$ peak increases for further increasing the annealing time up to $180 \mathrm{~min}$. In this work, we conducted experiments mostly in the range of room temperature to $70{ }^{\circ} \mathrm{C}$, intentionally avoiding the severe chemical degradation of the perovskite layer at higher temperatures. 
(a)

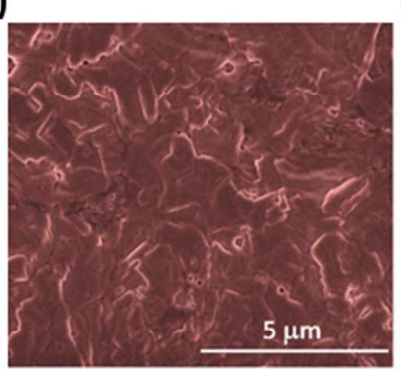

(d)

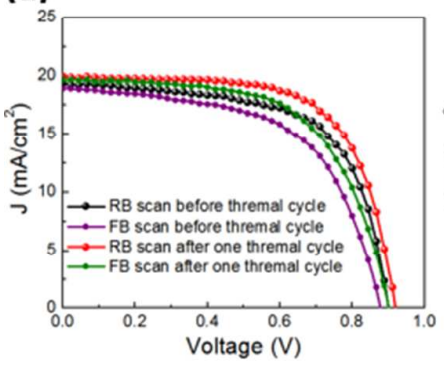

(b)

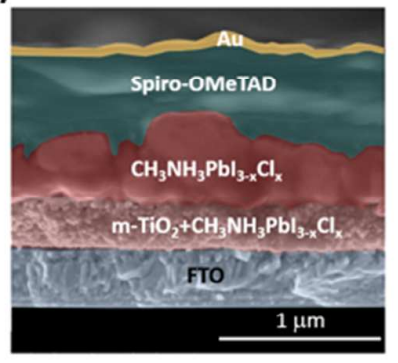

(e)

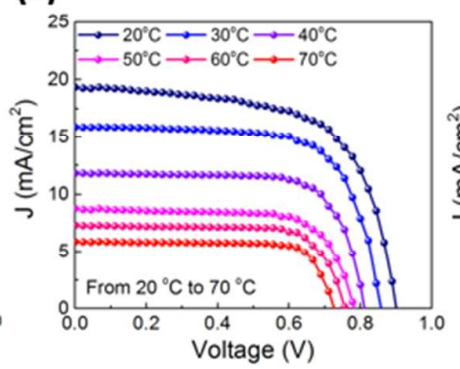

(c)

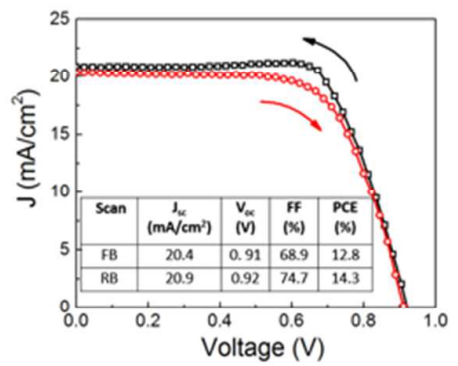

(f)

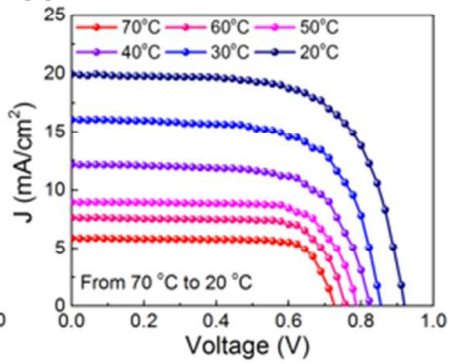

Figure 2. (a) Surface morphology of the $\mathrm{MAPbI}_{3-\mathrm{x}} \mathrm{Cl}_{\mathrm{x}}$ perovskite film deposited on meso$\mathrm{TiO}_{2}$. (b) Cross-sectional SEM image of the PSC. (c) $J-V$ curves of the best-performing device. (d) Comparison of the room-temperature $J-V$ characteristics of a typical PSC with hysteresis before and after the heat treatment at $70{ }^{\circ} \mathrm{C}$. Reverse bias (RB) refers to voltage scan from the open-circuit condition to the short-circuit condition; vice versa for forward bias (FB). Also shown are the $J-V$ characteristics of a typical PSC during thermal cycles of (e) 20 ${ }^{\circ} \mathrm{C}-70{ }^{\circ} \mathrm{C}$ and (f) $70{ }^{\circ} \mathrm{C}-20{ }^{\circ} \mathrm{C}$.

The top-view SEM image in Figure 2a confirmed that the $\mathrm{MAPbI}_{3-\mathrm{x}} \mathrm{Cl}_{\mathrm{x}}$ film was composed of homogeneous crystallized perovskite grains with complete $\mathrm{m}-\mathrm{TiO}_{2}$ surface coverage. The cross-sectional SEM image of the optimized device $\left(\mathrm{FTO} / \mathrm{c}-\mathrm{TiO}_{2} / \mathrm{m}\right.$ $\mathrm{TiO}_{2} / \mathrm{MAPbI}_{3-\mathrm{x}} \mathrm{Cl}_{\mathrm{x}} /$ spiro-OMeTAD/Au) in Figure $\mathbf{2 b}$ shows that the perovskite is completely infiltrated into the pores of the $\mathrm{mp}-\mathrm{TiO}_{2}$ film. Also, a uniform thick well-crystallized 
perovskite over layer with full surface coverage is formed, which eliminates the direct contact between the hole and electron transporters.

Figure 2c shows the $J$ - $V$ characteristics of the champion device measured under forward and reverse biases with a scan rate of $10 \mathrm{mVs}^{-1}$. Short-circuit photocurrent density $\left(J_{s c}\right)$ of $20.9 \mathrm{~mA} / \mathrm{cm}^{2}$, open-circuit voltage $\left(V_{o c}\right)$ of $0.92 \mathrm{~V}$, and fill factor $(\mathrm{FF})$ of $74.7 \%$ were observed, leading to PCE $(\eta)$ of $14.5 \%$. The average PCE of a batch of 24 solar cells is 12.5 $\%$, and the overall solar cell performance is quite reproducible; the statistical PCE data are shown in Figure S3, supporting information. We note here that optimization of PSC performance by adjusting the material and device processing parameters is not the focus of this work; although the PCE values are moderate compared to the reports in the literature, the conclusions we drew about the thermal effect on the photovoltaic effect should be general to the operation of other PSCs.

We first performed $J-V$ measurements on a typical PSC at different temperatures between $20{ }^{\circ} \mathrm{C}$ to $70{ }^{\circ} \mathrm{C}$. We note that hysteresis exists in the $J$-V characteristics of PSCs at all temperatures. Typical $J-V$ curves of PSC with hysteresis before and after the thermal cycle are shown in Figure 2d. Anomalous electrical hysteresis is commonly observed in PSCs, which may originate from effects such as defect-induced trap states ${ }^{48}$ and voltage-induced drift of ions ${ }^{49}$. Unless specified otherwise, all the $J$ - $V$ curves in this work were measured with the reversed bias, i.e., from the open-circuit condition to the short-circuit condition. Furthermore, we should point out that there appears to be an unexpected enhancement of PV performance in the PSC after the first thermal cycle, and the origin will be discussed in the next section.

Figures $2 \mathbf{e}$ and $\mathbf{2 f}$ show the $J-V$ characteristics of PSC measured at different temperatures during the heating and cooling cycles, respectively. Clearly, the photovoltaic performance of the PSCs strongly depends on the operating temperature of the device. At 20 
${ }^{\circ} \mathrm{C}$ the fresh PSC shows a PCE of $11.5 \%$ with $J_{s c}$ of $19.3 \mathrm{~mA} / \mathrm{cm}^{2}$, an open-circuit voltage $\left(V_{o c}\right) 0.90 \mathrm{~V}$ and a fill factor $(F F)$ of $64.8 \%$. The efficiency of PSC at the operating temperature of $70{ }^{\circ} \mathrm{C}$ dramatically dropped to $3.16 \%$ with $J_{s c}$ of $5.92 \mathrm{~mA} / \mathrm{cm}^{2}, V_{o c}$ of $0.72 \mathrm{~V}$ and $F F$ of $72.23 \%$. However, once the operating temperature of PSC returned to $20{ }^{\circ} \mathrm{C}$, the PCE increased to its original value with even notable improvement. The photovoltaic parameters of the PSC after the heating-cooling cycle yields a PCE of $12.6 \%$ with $J_{s c}$ of 20.1 $\mathrm{mA} / \mathrm{cm}^{2}, V_{o c}$ of $0.93 \mathrm{~V}$ and $F F$ of $66.4 \%$ at $20{ }^{\circ} \mathrm{C}$. This regenerative effect was quite reproducible and observed in a dozen of devices, and it will be discussed in details in the next section.

Figure 3a summarizes the temperature dependent $J_{s c}, V_{o c}, F F$ and PCE of the PSC measured during one heating and cooling cycle, which were derived from the $J-V$ data shown in Figures 2e and 2f. As the temperature of the PSC increased from $20{ }^{\circ} \mathrm{C}$ to $70{ }^{\circ} \mathrm{C}, J_{s c}$ gradually decreased from $19.3 \mathrm{~mA} / \mathrm{cm}^{2}$ to $5.9 \mathrm{~mA} / \mathrm{cm}^{2}$, in a quasi-linear fashion. When the temperature of PSC was reduced back to $20{ }^{\circ} \mathrm{C}, J_{s c}$ increased to $20.1 \mathrm{~mA} / \mathrm{cm}^{2}$, which was higher than the value measured before the thermal cycle. A similar temperature-dependent trend was observed for $V_{o c}$. In fact, at the open-circuit condition, with the assumption that the shunt resistance is much larger than the series resistance $\left(R_{\mathrm{sh}} \gg R_{\mathrm{S}}\right), V_{o c}$ can be expressed as: ${ }^{.50}$

$$
V_{o c}=\frac{n k T}{q} \ln \left(\frac{J_{s c}}{J_{0}}+1\right)
$$

where $J_{0}$ is the dark saturation current density, $n$ is the ideality factor, $q$ is the charge of an electron, and $k$ is the Boltzmann constant. Since the photocurrent density decreases with increasing temperature, the open circuit voltage also decreases in a similar fashion. On the other hand, as shown in Figure 3a, FF was found to increase with increasing temperature, which indicates the same temperature-dependent trend of the shunt resistance $R_{\mathrm{sh}}$. 
(a)

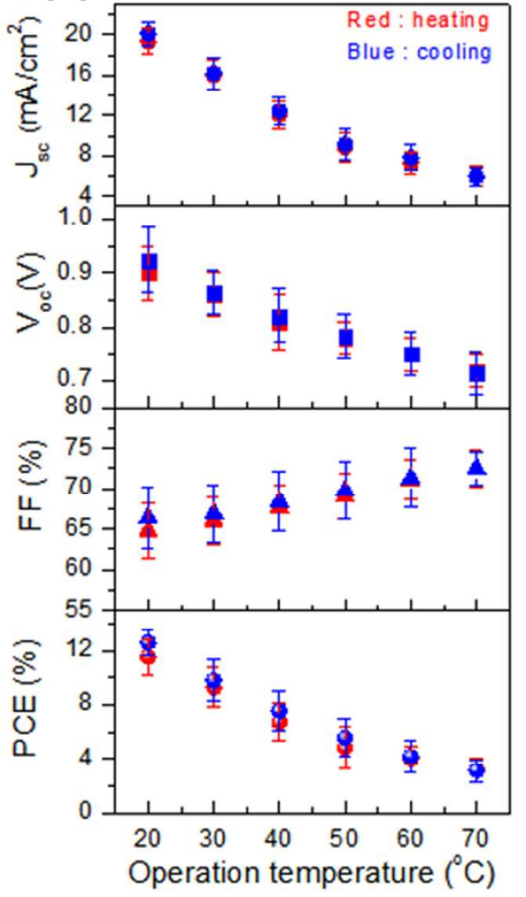

(b)
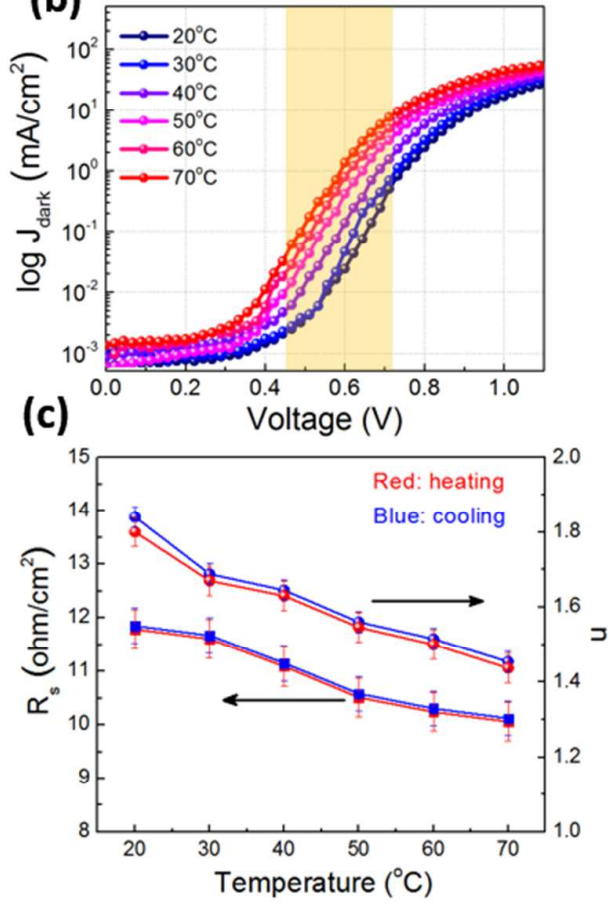

Figure 3. Temperature dependence of (a) $J_{s c}, V_{o c}, F F$ and PCE of the PSC measured during one heating (red points) /cooling (blue points) cycle. (b) Temperature-dependent dark $J$ - $V$ curves (the quasi-linear fitting region is highlighted). (c) Series resistance $R_{s}$ and ideality factor $n$ extracted from the dark $J-V$ curves.

Furthermore, to understand the temperature-dependent electrical behaviour of the PSCs, we analyzed the dark current data. Figure 3b shows the dark $J-V$ curves at different temperatures, which were fitted to the Schottky diode equation, ${ }^{51}$

$$
J=J_{s c}-J_{0} \exp \left(\frac{q\left(V+J R_{S}\right)}{n k T}\right)
$$

where $J_{0}$ is the saturation dark current and $V$ is the bias potential. By fitting the experimental data in the quasi-linear regions, we extracted series resistance $\left(R_{s}\right)$ and ideality factor $(n)$ for each temperature, as shown in Figure 3c. There are several insights we achieved from the data fitting. First, for a practical diode, both recombination current and diffusion current are involved, so the value of $n$ should lie in the range of 1 to $2 .^{52}$ Indeed, as shown in Figure 3c, 
the value of $n$ decreased from 1.80 at $20{ }^{\circ} \mathrm{C}$ to 1.42 at $70{ }^{\circ} \mathrm{C}$. Second, the substantial decrease of $n$ is responsible for the higher $F F$ of the PSC at higher operating temperatures (Figure 3a), which is in line with the previously reported relationship between ideality factor and $F F .{ }^{53}$ Third, in the PSC, both $R_{s}$ and $n$ decrease with increasing operation temperature. Equation 1 indicates that the $V_{o c}$ is directly proportional to the ideality factor $n$, and thus the reduction of the ideality factor at higher temperatures is responsible for the drop of $V_{o c}$. Finally, $R_{s}$ and $n$ regenerated back to their initial values after cooling down the device temperature from $70{ }^{\circ} \mathrm{C}$ to $20{ }^{\circ} \mathrm{C}$, indicating that the electronic processes, i.e. diffusion and/or recombination current are thermally reversible in these PSCs.

It is very important to note that the operating temperature $T_{0}$, or the temperature of the environment, is usually much lower than the actual solar cell temperature $T_{\mathrm{SC}}$. By neglecting the heat convection, $T_{\mathrm{SC}}$ can be calculated by the following equation, ${ }^{54}$

$$
T_{s c}=\left[T_{0}^{4}+\frac{1-\eta}{2 \times \sigma_{s}} P_{\text {sun }}\right]^{1 / 4}
$$

where $\eta$ is the efficiency of the solar cell, $\sigma_{\mathrm{s}}$ is the Stefan-Boltzmann constant, and $P_{\text {sun }}$ is the integrated power of the solar spectrum. Using the measured $\eta$ values and $\sigma_{\mathrm{s}}\left(5.67 \times 10^{-8} \mathrm{~W}\right.$ $\mathrm{m}^{-2} \mathrm{~K}^{-4}$ ), we calculated the solar cell temperature $T_{\mathrm{SC}}$. As shown in Figure 4, $T_{\mathrm{SC}}$ increases quasi-linearly with the operating temperature of the solar cell. At $20^{\circ} \mathrm{C}$, when the efficiency of PSC is $11.5 \%$, the actual temperature of the solar cell can rise to $77{ }^{\circ} \mathrm{C}$ during operation. At the maximum $T_{0}$ of $70{ }^{\circ} \mathrm{C}$ (outdoor summer temperature), the PSC efficiency decreases to $3.1 \%$, and the value of $T_{\mathrm{SC}}$ amounts to about $113{ }^{\circ} \mathrm{C}$. Hence, in a thermal environment with negligible thermal radiation, the actual temperature of PSC may rise close to the perovskite decomposition temperature of $120^{\circ} \mathrm{C}$. In the case of finite thermal radiative loss because of heat convection, the actual device temperature may be lower than $113{ }^{\circ} \mathrm{C}$, but presumably still higher than the operating temperature of $70{ }^{\circ} \mathrm{C}$. Furthermore, by distinguishing the solar 
cell temperature $T_{\mathrm{SC}}$ from the operating temperature $T_{0}$, we achieve an important insight on improving the stability of PSCs: according to equation 3, increasing the efficiency $\eta$ will help bring down $T_{\mathrm{SC}}$ and make the solar cell more stable.

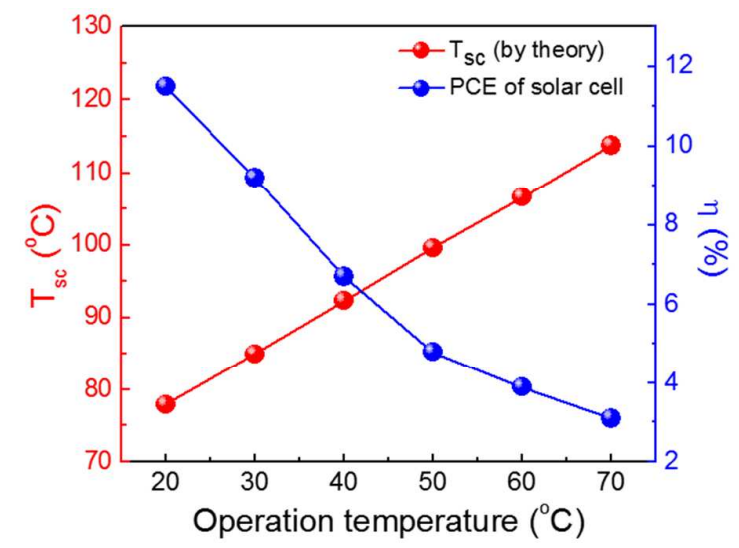

Figure 4. Variation of the calculated solar cell temperature $T_{\mathrm{SC}}$ with respect to the operating temperature $T_{0}$ of the PSC, along with the corresponding PCE values. It should be noted that the estimation neglects any thermal convection.

\subsection{Mechanism of the performance improvement after the first thermal cycle}

What is the origin of the PCE improvement observed after the thermal cycle? We excluded any modification of the perovskite layer because we did not find any structural change at $70{ }^{\circ} \mathrm{C}$ in the XRD experiments (Figure 1f). Also, we could exclude the possibility of modified mesoporous $\mathrm{TiO}_{2}$ because of its high processing temperature of $500{ }^{\circ} \mathrm{C}$.

In our previous report, ${ }^{32}$ we have shown that the solidification process in dry air drives the p-doping of spiro-OMeTAD, eventually leading to the PCE enhancement in PSCs at room temperature. Therefore, we suspected that the improved performance of PSC after the heating-cooling cycle could be attributed to the change of the spiro-OMeTAD layer. To examine this possibility, we performed XRD measurements on spiro-OMeTAD+LiTFSI+tBP powder scratched from the solid films cast on a glass substrate before and after annealing at 
$70{ }^{\circ} \mathrm{C}$. Figure 5a shows the comparison of the XRD patterns of spiro-OMeTAD with additives. We note that there is insufficient information in the literature on the polycrystalline structure of spiro-OMeTAD; thus we could not label the observed peaks. Nevertheless, the XRD data demonstrate that the intensities of the diffraction peaks at $14.04^{\circ}, 17.37^{\circ}$ and $22.35^{\circ}$ of the annealed spiro-OMeTAD sample increase as compared to the as-fabricated sample. This comparison indicates that the crystallinity of spiro-OMeTAD was improved after heating at $70{ }^{\circ} \mathrm{C}$. It has been reported that HTM with high crystallinity improves the photovoltaic performance of solar cells. ${ }^{55-56}$

To examine the effect of annealing on the electronic property of the spiro-OMeTAD layer, we analyzed the dark current density $\left(J_{d a r k}\right)$ versus voltage $(V)$ characteristics of the PSC (Figure 5b). The hole mobility was extracted by using the space charge limited current (SCLC) method. ${ }^{57}$ The SCLC-dominated $J-V$ characteristics can be described by the following equation,

$$
\frac{J}{V^{2}}=\frac{9 \varepsilon \varepsilon_{0} \mu}{8 d^{3}}
$$

where $\varepsilon$ is the dielectric constant (typically taken as 3 for organic semiconductors), ${ }^{58-59} \varepsilon_{0}$ is the permittivity of free space, $d$ is the film thickness, $V$ is the applied bias, and $\mu$ is the hole mobility. The SCLC method has been previously used to extract the hole mobility of undoped as well as modified spiro-OMeTAD. ${ }^{58-61}$ The effective hole mobility $\left(\mu_{\mathrm{HTM}}\right)$ for spiroOMeTAD was extracted by fitting the linear part (shaded region) of the $J^{1 / 2}$ versus $V$ curves, as shown in Figure 2b. The values of $\mu_{\mathrm{HTM}}$ were obtained as $1.12 \times 10^{-4} \mathrm{~cm}^{2} \mathrm{~V}^{-1} \mathrm{~s}^{-1}$ and 1.26 $\times 10^{-4} \mathrm{~cm}^{2} \mathrm{~V}^{-1} \mathrm{~s}^{-1}$ for the spiro-OMeTAD layer before and after the thermal treatment, respectively. The values of $\mu_{\mathrm{HTM}}$ acquired here are close to those reported in the literature. ${ }^{27}$ ${ }^{60-61}$ More importantly, this result confirms that the thermal treatment at $70{ }^{\circ} \mathrm{C}$ improves the hole mobility, which contributes to the enhanced photovoltaic performance of PSCs. 
The surface morphology of the spiro-OMeTAD layer of a freshly prepared PSC without the top Au electrode was examined using atomic force microscopy (AFM) with a heating stage. Top-view AFM image of the spiro-OMeTAD layer is shown in Figure 5c. There is no obvious morphological change after the annealing treatment at $70{ }^{\circ} \mathrm{C}$ (Figure 5d), and the root mean square (RMS) roughness is $6.2 \mathrm{~nm}$ for a scanning area of $25 \mu \mathrm{m}^{2}$. However, further heating to $100{ }^{\circ} \mathrm{C}$ increases the RMS roughness to $16.9 \mathrm{~nm}$ (Figure 5e), which is possibly due to the thermally induced degradation of the organic HTM. Spiro-OMeTAD has a glass transition temperature of $125{ }^{\circ} \mathrm{C}$ and the dopant 4-tert-butyl pyridine (t-BP) has an evaporation temperature of $85^{\circ} \mathrm{C} .{ }^{62}$

(a)

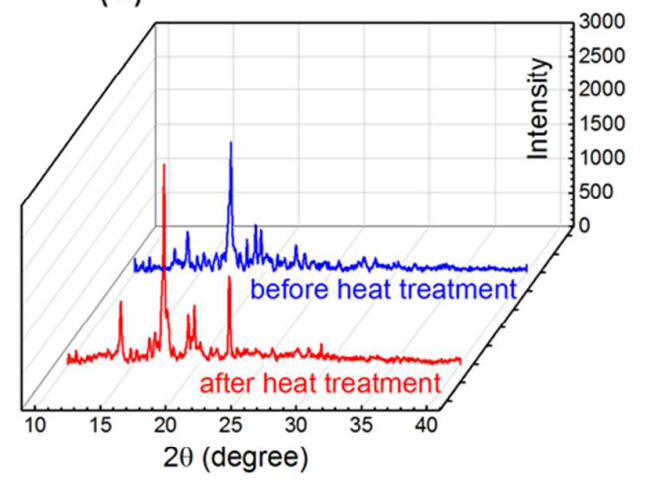

(c)

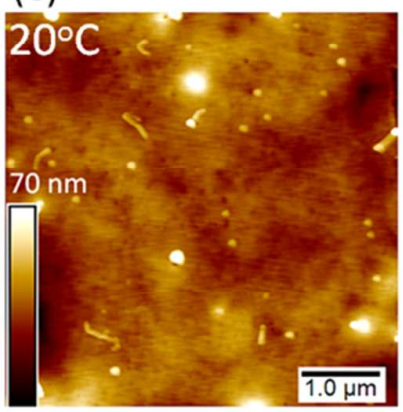

(d)

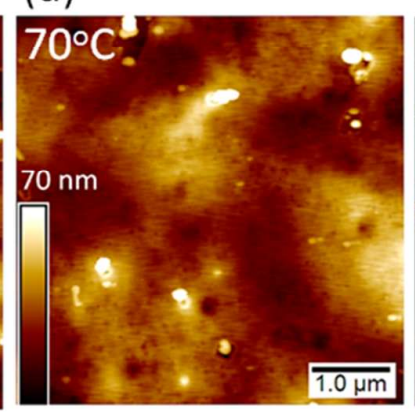

(b)

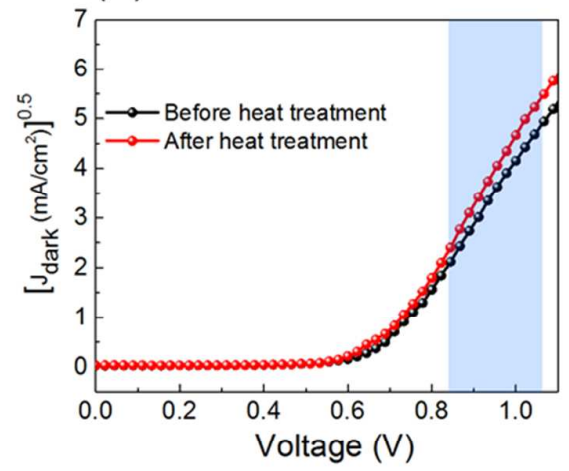

(e)

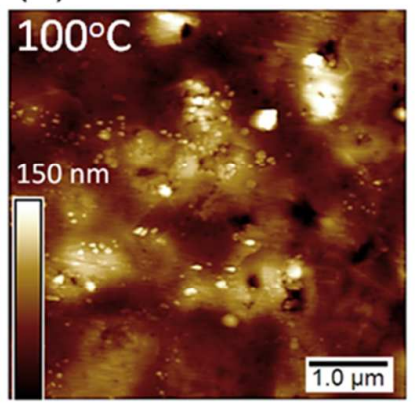

Figure 5. (a) XRD patterns of the spiro-OMeTAD+Li-TFSI+tBP powders. (b) Dark $J-V$ characteristic of the PSC before and after annealing at $70{ }^{\circ} \mathrm{C}$. The shaded area in (b) highlights the range of data where the mobility was extracted from fitting to the Schottky 
diode equation. Also shown are the top-view AFM images of the spiro-OMeTAD layers on top of the PSCs: (c) fresh, (d) after annealing at $70{ }^{\circ} \mathrm{C}$ and (e) after annealing at $100{ }^{\circ} \mathrm{C}$.

\subsection{Temperature-dependent IPCE and impedance measurements}

Figure 6a shows the IPCE spectra of the PSC as a function of measurement temperature. The broad mid-band response and the sharp tail towards the band gap cutoff indicate good carrier collection in the PSCs. The generation of photocurrent ends at the wavelength of $800 \mathrm{~nm}$, which is in good agreement with the bandgap of the $\mathrm{MAPbI}_{3-\mathrm{x}} \mathrm{Cl}_{\mathrm{x}}$. At $20{ }^{\circ} \mathrm{C}$, the highest IPCE value was observed at $555 \mathrm{~nm}$, in line with our previous report. ${ }^{32} \mathrm{On}$ increasing temperature, IPCE decreases over the whole wavelength range. In general, the IPCE depends mainly on the efficiency of exciton diffusion, charge transfer, and charge collection. ${ }^{14}$ Hence, the lower IPCE values at temperatures above $20{ }^{\circ} \mathrm{C}$ indicate lower charge transfer/collection efficiency and shorter carrier diffusion length, which is associated with the thermally enhanced charge trapping andrecombination. ${ }^{63-64}$ It was observed that at higher temperatures, the band edge cutoff becomes broader and the critical wavelength becomes slightly shorter, indicating a larger bandgap. ${ }^{65}$ The bandgap of hybrid perovskite increases at higher temperatures due to temperature-induced lattice expansion and/or electron-phonon interaction, ${ }^{66}$ which is in contrast to the behaviour of most semiconductors. Figure $6 \mathbf{b}$ show the variation of IPCE, or $\triangle \mathrm{IPCE}$, after heating the PSC to a different operating temperature from $20{ }^{\circ} \mathrm{C}$. It is interesting to note that $\triangle \mathrm{IPCE}$ appears to be more significant at longer wavelengths or near band edge. Figure 6c shows the comparison of temperature-dependent integrated current density $J_{s c}$ extracted from the IPCE data with the $J_{s c}$ values obtained from the illuminated $J-V$ curves. The good agreement indicates that the spectral mismatch between the solar simulator and the AM 1.5 standard solar emission is negligibly small, which validates the measurements. 

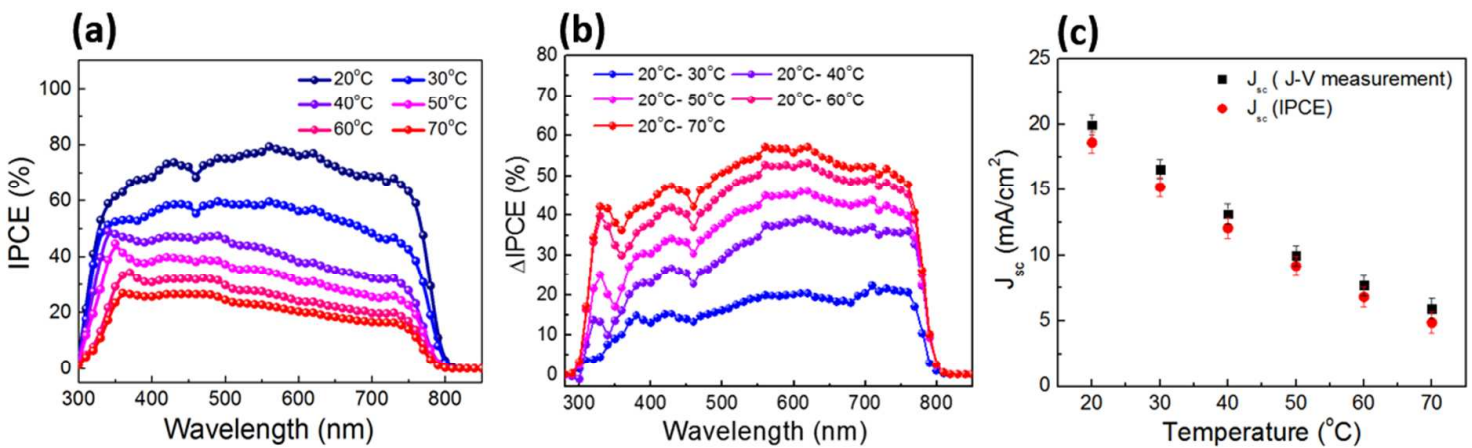

Figure 6. (a) IPCE of the PSC measured at different device operating temperatures. (b) Wavelength-dependent decrease of IPCE ( $\triangle \mathrm{IPCE})$ after heating to different operating temperatures. (c) Comparison of the integrated $J_{s c}$ extracted from the IPCE data and the $J_{s c}$ values directly from the $J-V$ measurements.

To precisely identify the temperature-induced variations in the charge transport and recombination processes in PSCs, we utilised the impedance spectroscopy. The Nyquist plots as a function of temperature are shown in Figure 7a. Details of the data in the high-frequency region are illustrated in Figure $\mathbf{7 b}$. The corresponding Bode plots can be found in Figure $\mathbf{S 4}$, Supporting Information. All the impedance measurements were carried out in the dark. ${ }^{67}$ In the Nyquist plots, the arc at high frequencies can be attributed to the charge transport process, whereas the arc at low frequencies is associated with the charge recombination process. ${ }^{6}$ Figures 7a-b show that the impedance curves possess a small semi circle in the highfrequency region and a much larger semi circle in the low-frequency region, indicating a low charge transfer resistance and a high recombination resistance. By fitting the impedance data to the equivalent RC circuit, charge transport resistance $\left(R_{t r}\right)$ and recombination resistance $\left(R_{r e c}\right)$ as a function of temperature are derived (Figure 7c). In general, $R_{t r}$ increases with the device temperature, indicating weaker charge transfer, whereas $R_{r e c}$ decreases with the device 
temperature because of the accelerated charge recombination. These results are consistent with the observed reductions in the photocurrent density and IPCE at higher temperatures.

(a)

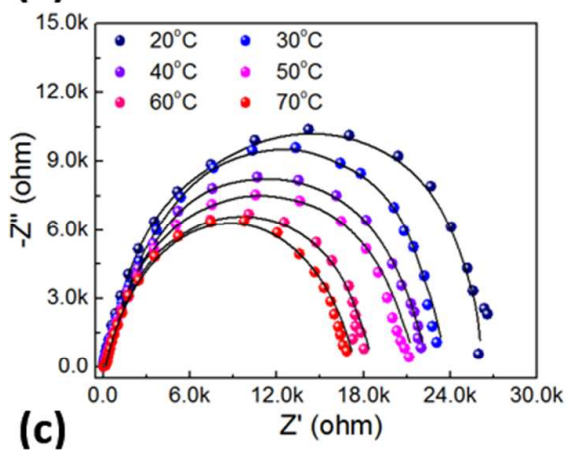

(c)

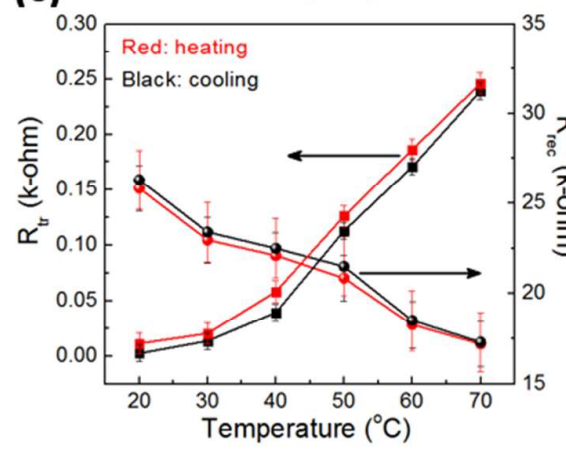

\section{(b)}

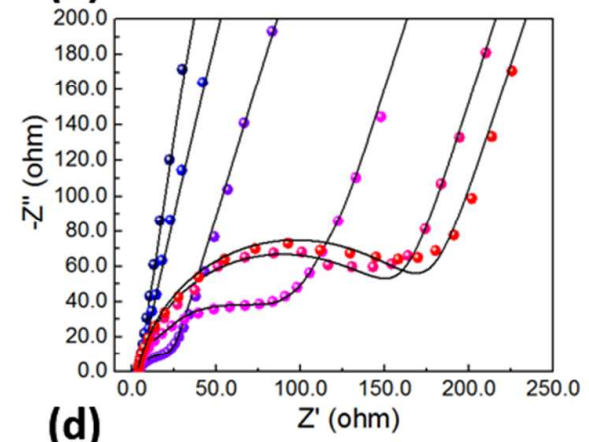

(d)

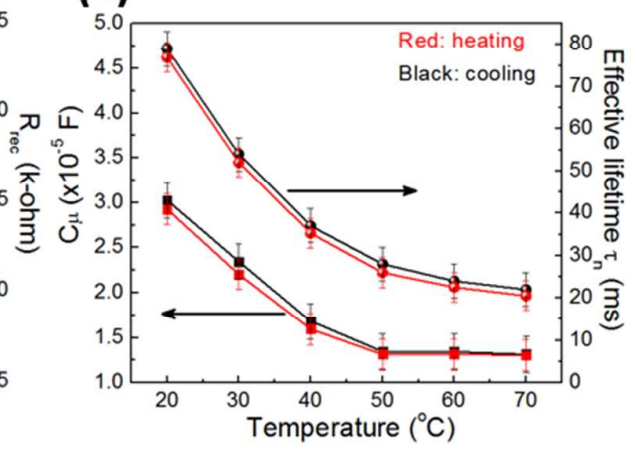

Figure 7. (a) Temperature dependent Nyquist plots collected on a PSC with the short-circuit condition. (b) Magnified high-frequency region. The lines in (a) and (b) represent the fitting results. (c) Extracted resistance values related to charge transfer $\left(R_{t r}\right)$ and charge recombination $\left(\mathrm{R}_{\mathrm{rec}}\right)$ as a function of operating temperature. (d) Temperature-dependent chemical capacitance along with effective lifetime $\left(\tau_{\mathrm{n}}\right)$ derived from the impedance data.

Figure $7 \mathbf{d}$ shows the temperature dependent behaviour of the chemical capacitance $\left(C_{\mu}\right)$ of PSCs extracted from the impedance measurements. It is known that the chemical capacitance is inversely proportional to the device temperature as shown below, ${ }^{69}$

$$
C_{\mu}=\frac{e^{2}}{k_{B} T} n
$$


where $e$ is the electron charge and $n$ is the total electron density. The increase of the operating temperature of the device increases the recombination current, which in turn generates more leakage paths to discharge the chemical capacitance. ${ }^{68}$ Furthermore, the electron lifetime $(\tau)$ was estimated from the relationship, $\tau=1 / 2 \pi f_{\max }$, where $f_{\max }$ is the frequency at which the complex impedance $\left(Z^{\prime \prime}\right)$ has its maximum value. The variation of a lifetime with the device operating temperature is shown in Figure 7d. The longest electron lifetime $\left(78 \mathrm{~ms}\right.$ ) for the PSC was observed at $20{ }^{\circ} \mathrm{C}$, and it monotonously decreases with increasing temperature, which is consistent with the higher charge recombination rate and reduced PSC performance at high temperatures. A similar trend of temperature-dependent electron lifetime was previously observed in dye-sensitized solar cells. ${ }^{70}$

\subsection{Effect of multiple thermal cycles on the PSC performance}
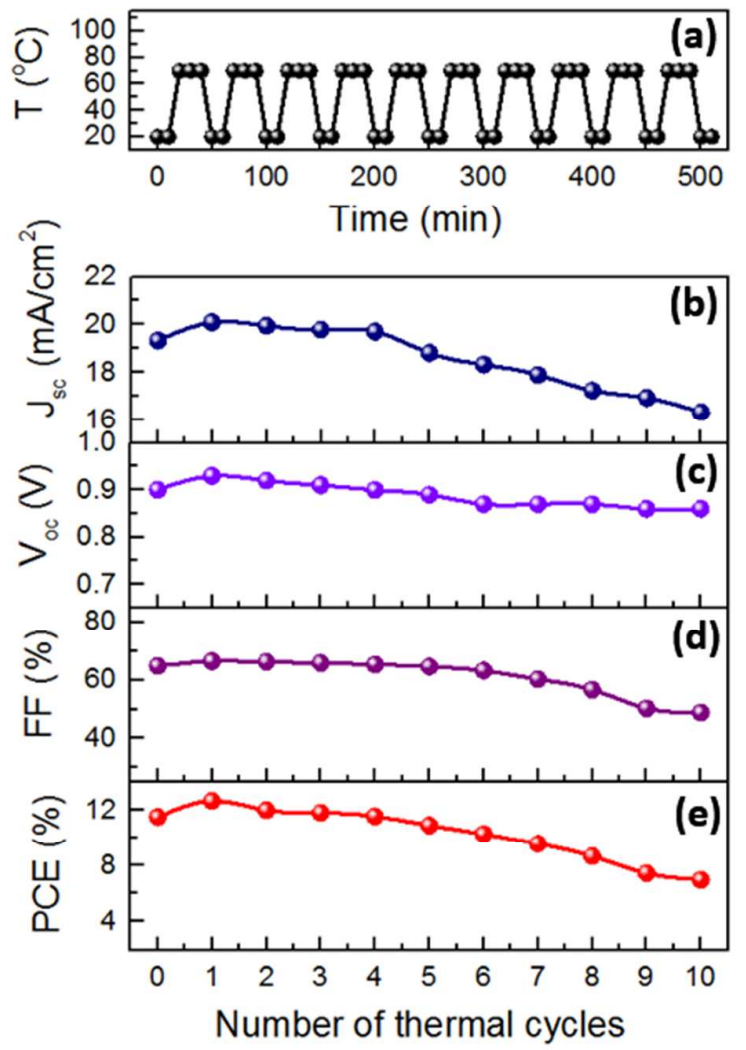
Figure 8. (a) Temperature-time profile of the thermal cycles. Photovoltaic parameters of (b) $J_{s c}$, (c) $V_{o c}$, (d) $F F$ and (e) PCE measured on the PSC over ten thermal cycles.

We further investigated the effect of repeated thermal cycles on the photovoltaic performance of PSCs, which is analogous to the day-to-day temperature variations for outdoor applications in some harsh environment. Figure 8a shows the time-dependent temperature profile. The photovoltaic parameters of PSC measured after each thermal cycle is shown in Figure 8 b-e. After the regenerative effect in the first cycle, the PCE of the PSC monotonously deteriorated in consecutive thermal cycles.

After ten thermal cycles, the PSC dropped to $6.6 \%$. Among the photovoltaic parameters, both $J_{s c}$ and $F F$ exhibited significant decreases, whereas the degradation of $V_{o c}$ appeared relatively moderate.

Table 1. Comparison of photovoltaic parameters, charge transport resistance $\left(\mathrm{R}_{\mathrm{tr}}\right)$, charge recombination resistance $\left(\mathrm{R}_{\text {rec }}\right)$ and charge carrier lifetime $\left(\tau_{n}\right)$ of a typical PSC right after fabrication, and after first and tenth thermal cycles.

\begin{tabular}{|c|c|c|c|c|c|c|c|}
\hline $\begin{array}{c}\text { Number of } \\
\text { thermal } \\
\text { cycles }\end{array}$ & $\begin{array}{c}\mathrm{J}_{\mathrm{sc}} \\
\left(\mathrm{mA} / \mathrm{cm}^{2}\right)\end{array}$ & $\begin{array}{c}\mathrm{V}_{\mathrm{oc}} \\
(\mathrm{V})\end{array}$ & $\begin{array}{c}\mathrm{FF} \\
(\%)\end{array}$ & $\begin{array}{c}\mathrm{PCE} \\
(\%)\end{array}$ & $\begin{array}{c}\mathrm{R}_{\mathrm{tr}} \\
(\mathrm{k} \Omega)\end{array}$ & $\begin{array}{c}\mathrm{R}_{\mathrm{rec}} \\
(\mathrm{k} \Omega)\end{array}$ & $\begin{array}{c}\tau_{\mathrm{n}} \\
(\mathrm{ms})\end{array}$ \\
\hline 0 & 19.34 & 0.90 & 64.8 & 11.5 & 0.014 & 25.83 & 76 \\
\hline 1 & 20.10 & 0.93 & 66.4 & 12.6 & 0.003 & 26.30 & 79 \\
\hline 10 & 16.32 & 0.86 & 48.8 & 6.98 & 0.085 & 17.64 & 48 \\
\hline
\end{tabular}

The thermal degradation of PSCs after multiple heating cycles could be caused by either the change of the light-absorbing perovskite layer itself or the deterioration of the interfacial charge transport. To discern the underlying mechanism, we performed XRD experiments on both the fresh PSC and the same PSC after ten thermal cycles (Figure S5 in supporting 
information). The XRD pattern of the PSC after 10 thermal cycles remains largely unchanged, indicating that the perovskite layer retained its phase and crystallinity without much degradation after repetitively heating to $70{ }^{\circ} \mathrm{C}$. Furthermore, there is no detectable change in both color and morphology of the PSC after the thermal cycles, indicating that the heating treatment did not produce irreversible detrimental effect to either the "bulk parts" inside of the perovskite or the charge transporting layers. Instead, the observed thermal degradation should be attributed to the high-temperature-induced modification of the interfaces in the PSCs and the resultant deterioration of the charge extraction process.

To gain insights on the internal electronic process of the PSC after thermal cycles, we performed impedance spectroscopy measurements. Table $\mathbf{1}$ shows the comparison of extracted parameters, $\mathbf{R}_{\text {tr }}, R_{\text {rec }}$ and $\tau$, for both the as-fabricated PSC and the same PSC after the first thermal cycle and after ten thermal cycles. The PSC after the first thermal cycle exhibited slightly lower $\mathrm{R}_{\mathrm{tr}}$, larger $\mathrm{R}_{\mathrm{rec}}$ and longer charge carrier lifetime as compared to the freshly prepared PSC. However, after the tenth thermal cycle, the value of $\mathrm{R}_{\mathrm{tr}}$ became much higher than that of the fresh PSC, whereas $\mathrm{R}_{\mathrm{rec}}$ and $\tau$ significantly dropped, which resulted in the sizable decrease of PCE. The impedance results unambiguously suggested significantly increased charge recombination at the $\mathrm{TiO}_{2} /$ perovskite and/or perovskite/spiro-OMeTAD interfacial layers, and the poor photo-carrier extraction at the interfaces led to the deterioration of the photovoltaic performance of PSCs after multiple thermal cycles.

\section{CONCLUSIONS}

In this work, we investigated the impact of high temperature and thermal cycling on the photovoltaic performance of PSCs. The in-situ GIWAXS, absorption and XRD measurements revealed that the phase formation of the perovskite layers in glove box occurred at approximately $100{ }^{\circ} \mathrm{C}$, while their rapid chemical decomposition in ambient air 
occurred at approximately $120{ }^{\circ} \mathrm{C}$. Although we limited our device test temperatures within the range from room temperature $\left(20^{\circ} \mathrm{C}\right)$ to $70{ }^{\circ} \mathrm{C}$, we still observed notable degradation of the solar cell performance, which indicates modifications related to the interfaces between the perovskite and the charge transporting layers. The improvement of PCE after the first thermal cycle between $20{ }^{\circ} \mathrm{C}$ and $70{ }^{\circ} \mathrm{C}$ can be attributed to the enhanced crystallinity and hole mobility of the hole-transporting spiro-OMeTAD layer. However, heating to temperatures above room temperature and repetitive thermal cycling bring a detrimental effect on the PCE of the PSCs. Specifically, our impedance spectroscopy analysis of the PSCs carried out at varying temperatures revealed the monotonous increase of charge transfer resistance and the concurrent decrease of charge recombination resistance on increasing temperature. The present investigation demonstrated that the development of efficient alternative HTMs with higher stability than spiro-OMeTAD is a prerequisite to design robust PSCs, and future microscopic investigations on the temperature-dependent modification of the interfaces in PSCs are needed to elucidate the chemical and structural origin of the device deterioration. Apparently, along with high temperature, humidity and light irradiation, thermal cycling poses a potent threat to the stability of PSCs, and future in-depth investigations in this direction are warranted to advance perovskite-based technologies in industrial-scale applications.

\begin{abstract}
ASSOCIATED CONTENT
Supporting Information.

The Supporting Information is available free of charge on the ACS Publications website at DOI:
\end{abstract}


Figures show the measurement setup for the temperature-dependent PSC performance, in-situ XRD spectra of $\mathrm{MAPbI}_{3-\mathrm{x}} \mathrm{Cl}_{\mathrm{x}}$ thin film after annealing for different time intervals, performance statistics, temperature-dependent Bode plot and structural stability of PSCs.

\section{AUTHOR INFORMATION}

\section{Corresponding Author}

*Email: tao.wu@kaust.edu.sa

\section{Notes}

The authors declare no competing financial interests.

\section{ACKNOWLEDGMENTS}

Research reported in this publication was supported by King Abdullah University of Science and Technology (KAUST), Saudi Arabia. CHESS is supported by the NSF \& NIH/NIGMS via NSF award DMR-1332208.

\section{REFERENCES}

(1) Kojima, A.; Teshima, K.; Shirai, Y.; Miyasaka, T. Organometal Halide Perovskites as Visible-Light Sensitizers for Photovoltaic Cells. J. Am. Chem. Soc. 2009, 131, 6050-6051.

(2) Li, X.; Bi, D.; Yi, C.; Décoppet, J. D.; Luo, J.; Zakeeruddin, S. M.; Hagfeldt, A.; Grätzel, M. A Vacuum Flash-Assisted Solution Process For High-Efficiency Large-Area Perovskite Solar Cells. Science 2016, DOI: 10.1126/science.aaf8060.

(3) Saliba, M.; Matsui, T.; Seo, J.-Y.; Domanski, K.; Correa-Baena, J.-P.; Nazeeruddin, M. K.; Zakeeruddin, S. M.; Tress, W.; Abate, A.; Hagfeldt, A.; Gratzel, M. CesiumContaining Triple Cation Perovskite Solar Cells: Improved Stability, Reproducibility And High Efficiency. Energy Environ. Sci. 2016, 9, 1989-1997. 
(4) Best Research-Cell Efficiencies, N. R. E. L., www.nrel.gov/ncpv/images/efficiency chart.jpg.

(5) Snaith, H. J. Perovskites: The Emergence of a New Era for Low-Cost, HighEfficiency Solar Cells. J. Phys. Chem. Lett. 2013, 4, 3623-3630.

(6) Kim, H. S.; Lee, C. R.; Im, J. H.; Lee, K. B.; Moehl, T.; Marchioro, A.; Moon, S. J.; Humphry-Baker, R.; Yum, J. H.; Moser, J. E.; Gratzel, M.; Park, N. G. Lead Iodide Perovskite Sensitized All-Solid-State Submicron Thin Film Mesoscopic Solar Cell With Efficiency Exceeding 9\%. Sci Rep 2012, 2, 591.

(7) Mitzi, D. B.; Feild, C. A.; Harrison, W. T. A.; Guloy, A. M. Conducting Tin Halides With A Layered Organic-Based Perovskite Structure. Nature 1994, 369, 467-469.

(8) Mitzi, D. B.; Wang, S.; Feild, C. A.; Chess, C. A.; Guloy, A. M. Conducting Layered Organic-Inorganic Halides Containing (110)-Oriented Perovskite Sheets. Science 1995, 267, 1473-1476.

(9) Noh, J. H.; Im, S. H.; Heo, J. H.; Mandal, T. N.; Seok, S. I. Chemical Management for Colorful, Efficient, and Stable Inorganic-Organic Hybrid Nanostructured Solar Cells. Nano Lett. 2013, 13, 1764-1769.

(10) Pellet, N.; Gao, P.; Gregori, G.; Yang, T.-Y.; Nazeeruddin, M. K.; Maier, J.; Grätzel, M. Mixed-Organic-Cation Perovskite Photovoltaics for Enhanced Solar-Light Harvesting. Angew. Chem. Int. Ed. 2014, 53, 3151-3157.

(11) Xing, G.; Mathews, N.; Sun, S.; Lim, S. S.; Lam, Y. M.; Gratzel, M.; Mhaisalkar, S.; Sum, T. C. Long-Range Balanced Electron and Hole Transport Lengths in Organic-Inorganic $\mathrm{CH}_{3} \mathrm{NH}_{3} \mathrm{PbI}_{3}$. Science 2013, 342, 344-347.

(12) Stranks, S. D.; Eperon, G. E.; Grancini, G.; Menelaou, C.; Alcocer, M. J.; Leijtens, T.; Herz, L. M.; Petrozza, A.; Snaith, H. J. Electron-Hole Diffusion Lengths Exceeding 1 Micrometer in an Organometal Trihalide Perovskite Absorber. Science 2013, 342, 341-344. 
(13) Liu, D.; Kelly, T. L. Perovskite Solar Cells With A Planar Heterojunction Structure Prepared Using Room-Temperature Solution Processing Techniques. Nat. Photonics 2014, 8, 133-138.

(14) Sun, S.; Salim, T.; Mathews, N.; Duchamp, M.; Boothroyd, C.; Xing, G.; Sum, T. C.; Lam, Y. M. The Origin Of High Efficiency In Low-Temperature Solution-Processable Bilayer Organometal Halide Hybrid Solar Cells. Energy Environ. Sci. 2014, 7, 399-407.

(15) Zhao, Y.; Zhu, K. Solution Chemistry Engineering toward High-Efficiency Perovskite Solar Cells. J. Phys. Chem. Lett. 2014, 5, 4175-4186.

(16) Heo, J. H.; Im, S. H.; Noh, J. H.; Mandal, T. N.; Lim, C.-S.; Chang, J. A.; Lee, Y. H.; Kim, H.-j.; Sarkar, A.; Nazeeruddin, M. K.; Grätzel, M.; Seok, S. I. Efficient InorganicOrganic Hybrid Heterojunction Solar Cells Containing Perovskite Compound And Polymeric Hole Conductors. Nat. Photonics 2013, 7, 486-491.

(17) Leijtens, T.; Lauber, B.; Eperon, G. E.; Stranks, S. D.; Snaith, H. J. The Importance of Perovskite Pore Filling in Organometal Mixed Halide Sensitized $\mathrm{TiO}_{2}$-Based Solar Cells. J. Phys. Chem. Lett. 2014, 5, 1096-1102.

(18) Eperon, G. E.; Burlakov, V. M.; Docampo, P.; Goriely, A.; Snaith, H. J. Morphological Control for High Performance, Solution-Processed Planar Heterojunction Perovskite Solar Cells. Adv. Funct. Mater. 2014, 24, 151-157.

(19)Barrit, D.; Sheikh, A. D.; Munir, R.; Barbé, J. M.; Li, R.; Smilgies, D. M.; Amassian, A. Hybrid Perovskite Solar Cells: In Situ Investigation of Solution Processed $\mathrm{PbI}_{2}$ Reveals Metastable Precursors and a Pathway to Producing Porous Thin Films. J. Mater. Res. 2017, 1-9, DOI: https://doi.org/10.1557/jmr.2017.117.

(20) Munir,R.; Sheikh, A. D.; Abdelsamie, M.; Hu,H.; YuL.; ZhaoK.;KimT.; Tall O. E.;Li, R.;Smilgies, D. M.; Amassian, A. Hybrid Perovskite Thin-Film Photovoltaics: In Situ Diagnostics and Importance of the Precursor Solvate Phases. Adv. Mater. 2017, 29, 1604113. 
(21) Jeon, N. J.; Noh, J. H.; Kim, Y. C.; Yang, W. S.; Ryu, S.; Seok, S. I. Solvent Engineering For High-Performance Inorganic-Organic Hybrid Perovskite Solar Cells. Nat. Mater. 2014, 13, 897-903.

(22) Wang, B.; Wong Y., K.; Xiao, X.; Chen, T. Elucidating the Reaction Pathways in the Synthesis of Organolead Trihalide Perovskite for High-Performance Solar Cells. Sci. Rep. 2015, 5, 10557.

(23) Tao, C.; Neutzner, S.; Colella, L.; Marras, S.; KandadaS., A. R.; Gandini, M.; Bastiani, M. D.; Pace, G.; Manna, L.; Caironi, M.; Bertarelli, C.; Petrozza, A. 17.6\% Stabilized Efficiency In Low-Temperature Processed Planar Perovskite Solar Cells. Energy Environ. Sci. 2015, 8, 2365-2370.

(24) Yin, G.; Ma, J.; Jiang, H.; Li, J.; Yang, D.; Gao, F.; Zeng, Z.; Liu, Z.; Liu, S. F. Enhancing Efficiency and Stability of Perovskite Solar Cells Through Nb-Doping of $\mathrm{TiO}_{2}$ at Low Temperature. ACS Appl. Mater. Interfaces, 2017, 9, 10752-10758.

(25) Bera, A.; Wu, K. W.; Sheikh, A.; Alarousu, E.; Mohammed, O. F.; Wu, T. Perovskite Oxide $\mathrm{SrTiO}_{3}$ as an Efficient Electron Transporter for Hybrid Perovskite Solar Cells. J. Phys. Chem. C 2014, 118, 28494-28501.

(26) Bera, A.; Sheikh, A. D.; Haque, M. A.; Bose, R.; Alarousu, E.; Mohammed, O. F.; Wu, T. Fast Crystallization and Improved Stability of Perovskite Solar Cells with $\mathrm{Zn}_{2} \mathrm{SnO}_{4}$ Electron Transporting Layer: Interface Matters. ACS Appl. Mater. Interfaces 2015, 7, 2840428411.

(27) Wang, H.; Sheikh, A. D.; Feng, Q.; Li, F.; Chen, Y.; Yu, W.; Alarousu, E.; Ma, C.; Haque, M. A.; Shi, D.; Wang, Z. S.; Mohammed, O. F.; Bakr, O. M.; Wu, T. Facile Synthesis and High Performance of a New Carbazole-Based Hole-Transporting Material for Hybrid Perovskite Solar Cells. ACS Photonics 2015, 2, 849-855. 
(28) Rao, H.; Sun, W.; Ye, S.; Yan, W.; Li, Y.; Peng, H.; Liu, Z.; Bian, Z.; Huang, C. Solution-Processed CuS NPs as an Inorganic Hole-Selective Contact Material for Inverted Planar Perovskite Solar Cells. ACS Appl. Mater. Interfaces 2016, 8, 7800-7805.

(29) Tong, S. W.; Balapanuru, J.; Fu, D.; Loh, K. P. Solution-Processable Ionic Liquid as an Independent or Modifying Electron Transport Layer for High-Efficiency Perovskite Solar Cells. ACS Appl. Mater. Interfaces 2016, 8, 34464-34473.

(30) Yu, W.; eng Li,F.; Wang, H.; Alarousu, E.; Chen, Y.; Lin,B.; Wang, L.; Hedhili, M. N.; Li Y.; Wu,K.; Wang, X.; Mohammed, O. F.; Wu, T. Ultrathin $\mathrm{Cu}_{2} \mathrm{O}$ as an Efficient Inorganic Hole Transporting Material For Perovskite Solar Cells. Nanoscale, 2016, 8, 6173-6179

(31) Haque, M. A.; Sheikh, A. D.; Guan X.; Wu, T. Metal Oxides as Efficient Charge Transporters in Perovskite Solar Cells. Adv. Energy Mater. 2017, 1602803, DOI: 10.1002/aenm.201602803.

(32) Sheikh, A. D.; Bera, A.; Haque, M. A.; Rakhi, R. B.; Gobbo, S. D.; Alshareef, H. N.; Wu, T. Atmospheric Effects On The Photovoltaic Performance of Hybrid Perovskite Solar Cells. Sol. Energy Mater. Sol. Cells 2015, 137, 6-14.

(33) Leijtens, T.; Eperon, G. E.; Noel, N. K.; Habisreutinger, S. N.; Petrozza, A.; Snaith, H. J. Stability of Metal Halide Perovskite Solar Cells. Adv. Energy Mater. 2015, 5, 1500963.

(34) Park, N. G.; Grätzel, M.; Miyasaka, T.; Zhu, K.; Emery, K. Towards Stable And Commercially Available Perovskite Solar Cells. Nat. Energy 2016, 1, 16152.

(35) Christians, J. A.; Miranda Herrera, P. A.; Kamat, P. V. Transformation of the Excited State and Photovoltaic Efficiency of $\mathrm{CH}_{3} \mathrm{NH}_{3} \mathrm{PbI}_{3}$ Perovskite upon Controlled Exposure to Humidified Air. J. Am. Chem. Soc. 2015, 137, 1530-1538.

(36) Niu, G.; Guo, X.; Wang, L. Review Of Recent Progress In Chemical Stability Of Perovskite Solar Cells. J. Mater. Chem. A 2015, 3, 8970-8980. 
(37) Aristidou, N.; Sanchez-Molina, I.; Chotchuangchutchaval, T.; Brown, M.; Martinez, L.; Rath, T.; Haque, S. A. The Role of Oxygen in the Degradation of Methylammonium Lead Trihalide Perovskite Photoactive Layers. Angew. Chem. Int. Ed. 2015, 54, 8208-8212.

(38) Rong, Y.; Liu, L.; Mei, A.; Li, X.; Han, H. Beyond Efficiency: the Challenge of Stability in Mesoscopic Perovskite Solar Cells. Adv. Energy Mater. 2015, 5, 1501066.

(39) Li, X.; Tschumi, M.; Han, H.; Babkair, S. S.; Alzubaydi, R. A.; Ansari, A. A.; Habib, S. S.; Nazeeruddin, M. K.; Zakeeruddin, S. M.; Grätzel, M. Outdoor Performance and Stability under Elevated Temperatures and Long-Term Light Soaking of Triple-Layer Mesoporous Perovskite Photovoltaics. Energy Technol. 2015, 3, 551-555.

(40) Milot, R. L.; Eperon, G. E.; Snaith, H. J.; Johnston, M. B.; Herz, L. M. TemperatureDependent Charge-Carrier Dynamics in $\mathrm{CH}_{3} \mathrm{NH}_{3} \mathrm{PbI}_{3}$ Perovskite Thin Films. Adv. Funct. Mater. 2015,25, 6218-6227.

(41) Aharon, S.; Dymshits, A.; Rotem, A.; Etgar, L. Temperature Dependence of Hole Conductor Free Formamidinium Lead Iodide Perovskite Based Solar Cells. J. Mater. Chem. A 2015, 3, 9171-9178.

(42) Ren, Z.; Ng, A.; Shen, Q.; Gokkaya, H. C.; Wang, J.; Yang, L.; Yiu, W. K.; Bai, G.; Djurišić, A. B.; Leung, W. W.; Hao, J.; Chan, W. K.; Surya, C. Thermal Assisted Oxygen Annealing for High Efficiency Planar $\mathrm{CH}_{3} \mathrm{NH}_{3} \mathrm{PbI}_{3}$ Perovskite Solar Cells. Sci. Rep. 2014, 4, 6752.

(43) Divitini, G.; Cacovich, S.; Matteocci, F.; Cinà, L.; Di Carlo, A.; Ducati, C. In-situ Observation Of Heat-Induced Degradation of Perovskite Solar Cells. Nat. Energy 2016, 1, 15012.

(44) Domanski, K.; Correa-Baena, J.-P.; Mine, N.; Nazeeruddin, M. K.; Abate, A.; Saliba, M.; Tress, W.; Hagfeldt, A.; Grätzel, M. Not All That Glitters Is Gold: Metal-MigrationInduced Degradation in Perovskite Solar Cells. ACS Nano 2016, 10, 6306-6314. 
(45) Baikie, T.; Fang, Y.; Kadro, J. M.; Schreyer, M.; Wei, F.; Mhaisalkar, S. G.; Graetzel, M.; White, T. J. Synthesis and Crystal Chemistry of the Hybrid Perovskite $\left(\mathrm{CH}_{3} \mathrm{NH}_{3}\right) \mathrm{PbI}_{3}$ For Solid-State Sensitised Solar Cell Applications. J. Mater. Chem. A 2013, 1, 5628-5641.

(46) Supasai, T.; Rujisamphan, N.; Ullrich, K.; Chemseddine, A.; Dittrich, T. Formation of a passivating $\mathrm{CH}_{3} \mathrm{NH}_{3} \mathrm{PbI}_{3} / \mathrm{PbI}_{2}$ interface during moderate heating of $\mathrm{CH}_{3} \mathrm{NH}_{3} \mathrm{PbI}_{3}$ layers. Appl. Phys. Lett. 2013, 103, 183906.

(47) Dualeh, A.; Tétreault, N.; Moehl, T.; Gao, P.; Nazeeruddin, M. K.; Grätzel, M. Effect of Annealing Temperature on Film Morphology of Organic-Inorganic Hybrid Pervoskite SolidState Solar Cells. Adv. Funct. Mater. 2014, 24, 3250-3258.

(48) Snaith, H. J.; Abate, A.; Ball, J. M.; Eperon, G. E.; Leijtens, T.; Noel, N. K.; Stranks, S. D.; Wang, J. T.-W.; Wojciechowski, K.; Zhang, W. Anomalous Hysteresis in Perovskite Solar Cells. J. Phys. Chem. Lett. 2014, 5, 1511-1515.

(49) Xiao, Z.; Yuan, Y.; Shao, Y.; Wang, Q.; Dong, Q.; Bi, C.; Sharma, P.; Gruverman, A.; Huang, J. Giant Switchable Photovoltaic Effect in Organometal Trihalide Perovskite Devices. Nat. Mater. 2015, 14, 193-198.

(50) Elumalai, N. K.; Uddin, A., Open Circuit Voltage of Organic Solar Cells: An In-Depth Review. Energy Environ. Sci., 2016, 9, 391-410.

(51) Im, J. H.; Jang, I. H.; Pellet, N.; Gratzel, M.; Park, N. G. Growth of $\mathrm{CH}_{3} \mathrm{NH}_{3} \mathrm{PbI}_{3}$ Cuboids With Controlled Size For High-Efficiency Perovskite Solar Cells. Nat. Nanotech. 2014, 9, 927-932.

(52) Qi, B.; Wang, J. Open-Circuit Voltage In Organic Solar Cells. J. Mater. Chem. 2012, 22, $24315-24325$.

(53) Zhu, K.; Jang, S. R.; Frank, A. J. Impact of High Charge-Collection Efficiencies and Dark Energy-Loss Processes on Transport, Recombination, and Photovoltaic Properties of Dye-Sensitized Solar Cells. J. Phys. Chem. Lett. 2011, 2, 1070-1076. 
(54) Dittrich, T. Materials Concepts for Solar Cells, Imperial College Press, London, 2014.

(55) Fang, Y.; Wang, X.; Wang, Q.; Huang, J.; Wu, T. Impact Of Annealing On SpiroOmetad And Corresponding Solid-State Dye Sensitized Solar Cells. phys. status solidi A. 2014, 211, 2809-2816.

(56) Kumar, R. S. S.; Grancini, G.; Petrozza, A.; Abrusci, A.; Snaith, H. J.; Lanzani, G. Effect Of Polymer Morphology On P3HT-Based Solid-State Dye Sensitized Solar Cells: An Ultrafast Spectroscopic Investigation. Opt. Express 2013, 21, A469-A474.

(57) Agarwal, S.; Seetharaman, M.; Kumawat, N. K.; Subbiah, A. S.; Sarkar, S. K.; Kabra, D.; Namboothiry, M. A. G.; Nair, P. R. On the Uniqueness of Ideality Factor and Voltage Exponent of Perovskite-Based Solar Cells. J. Phys. Chem. Lett. 2014, 5, 4115-4121.

(58) Poplavskyy, D.; Nelson, J. Nondispersive Hole Transport In Amorphous Films Of Methoxy-Spirofluorene-Arylamine Organic Compound. J. Appl. Phys. 2003, 93, 341.

(59) Snaith, H. J.; Grätzel, M. Enhanced Charge Mobility In A Molecular Hole Transporter Via Addition Of Redox Inactive Ionic Dopant: Implication To Dye-Sensitized Solar Cells. Appl. Phys. Lett. 2006, 89, 262114.

(60) Abate, A.; Leijtens, T.; Pathak, S.; Teuscher, J.; Avolio, R.; Errico, M. E.; Kirkpatrik, J.; Ball, J. M.; Docampo, P.; McPherson, I.; Snaith, H. J. Lithium Salts As "Redox Active" PType Dopants For Organic Semiconductors And Their Impact In Solid-State Dye-Sensitized Solar Cells. Phys. Chem. Chem. Phys. 2013,15, 2572-2579.

(61) Leijtens, T.; Ding, I. K.; Giovenzana, T.; Bloking, J. T.; McGehee, M. D.; Sellinger, A. Hole Transport Materials with Low Glass Transition Temperatures and High Solubility for Application in Solid-State Dye-Sensitized Solar Cells. ACS Nano 2012,6, 1455-1462.

(62) Bailie, C. D.; Unger, E. L.; Zakeeruddin, S. M.; Gratzel, M.; McGehee M. D. MeltInfiltration of Spiro-Ometad and Thermal Instability of Solid-State Dye-Sensitized Solar Cells. Phys. Chem. Chem. Phys. 2014, 16, 4864-4870. 
(63) Wehrenfennig, C.; Liu, M.; Snaith, H. J.; Johnston, M. B.; Herz, L. M. Charge Carrier Recombination Channels In The Low-Temperature Phase of Organic-Inorganic Lead Halide Perovskite Thin Films. APL Mater. 2014, 2, 081513.

(64) Leong, W. L.; Ooi, Z.-E.; Sabba, D.; Yi, C.; Zakeeruddin, S. M.; Graetzel, M.; Gordon, J. M.; Katz, E. A.; Mathews, N. Identifying Fundamental Limitations in Halide Perovskite Solar Cells. Adv. Mater. 2016, 28, 2439-2445.

(65) Wu, K.; Bera, A.; Ma, C.; Du, Y.; Yang, Y.; Li, L.; Wu, T. Temperature-Dependent Excitonic Photoluminescence of Hybrid Organometal Halide Perovskite Films. Phys. Chem. Chem. Phys.2014, 16, 22476-22481.

(66) Yu, C.; Chen, Z.; J. Wang, J.; Pfenninger, W.; Vockic, N.; Kenney, J. T.; Shum, K. Temperature Dependence of the Band Gap of Perovskite Semiconductor Compound CsSnI 3 . J. Appl. Phys. 2011, 110, 063526.

(67) Fabregat-Santiago, F.; Bisquert, J.; Cevey, L.; Chen, P.; Wang, M.; Zakeeruddin, S. M.; Grätzel, M. Electron Transport and Recombination in Solid-State Dye Solar Cell with SpiroOMeTAD as Hole Conductor. J. Am. Chem. Soc. 2009, 131 , 558-562.

(68) Dualeh, A.; Moehl, T.; Nazeeruddin, M. K.; Grätzel, M. Temperature Dependence of Transport Properties of Spiro-MeOTAD as a Hole Transport Material in Solid-State DyeSensitized Solar Cells. ACS Nano 2013, 7, 2292-2301.

(69) Bisquert, J. Chemical Capacitance of Nanostructured Semiconductors: Its Origin And Significance For Nanocomposite Solar Cells. Phys. Chem. Chem. Phys. 2003, 5, 5360-5364.

(70) Rock, S. E.; Shi, X.; Garland, J. E.; Roy, D. Experimental Considerations For Temperature Controlled Measurements of Fast Charge Recombination Times in Dye Sensitized Solar Cells Using Open Circuit Voltage Decay And Impedance Spectroscopy. Measurement 2014, 53, 71-82. 


\section{TOC GRAPHICS}

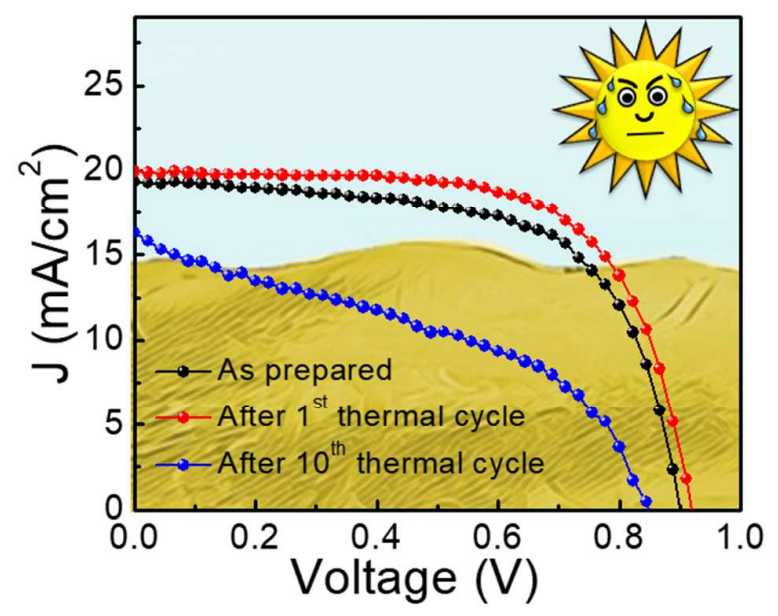

